\title{
Skipping breakfast among preschoolers: associated factors and its dose-response relationship with overweight/obesity
}

\author{
Omissão de desjejum em pré-escolares: \\ fatores associados e sua relação \\ dose-dependência com \\ excesso de peso
}

\author{
Ana Carolina Vieira de Teixeira GUIMARÃES1 (ID) 0000-0001-5274-2063 \\ Camila Kellen de Souza CARDOSO² (iD) 0000-0002-1246-5572 \\ Luciana Bronzi de SOUZA3 (ID) 0000-0002-4525-1618 \\ Marília Mendonça GUIMARÃES 3 (ID) 0000-0003-1466-6180 \\ Maria do Rosário Gondim PEIXOTO1 ID 0000-0003-1950-0817
}

A B S T R A C T

\section{Objective}

To investigate factors associated with skipping breakfast in preschoolers and test a dose-dependent relationship between the frequency of breakfast consumption and the prevalence of overweight/obesity.

1 Universidade Federal de Goiás, Faculdade de Nutrição, Programa de Pós-Graduação em Nutrição e Saúde. R. 227, Quadra 68, Setor Universitário, 74605-08, Goiânia, GO, Brasil. Correspondence to: M. R. G. PEIXOTO. E-mail: <mrg.peixoto@uol.com.br>.

2 Pontifícia Universidade Católica de Goiás, Escola de Ciências Sociais e da Saúde, Curso de Nutrição. Goiânia, GO, Brasil.

3 Universidade Federal de Goiás, Faculdade de Nutrição, Área de Saúde Coletiva. Goiânia, GO, Brasil.

Support: Fundação de Amparo à Pesquisa do Estado de Goiás (FAPEG, State of Goiás Research Suppor Foundation) (Processo No. 201010267000924).

Article elaborated from dissertation by ACT GUIMARÃES, entitled "Consumption and quality of breakfast among preschoolers". Universidade Federal de Goiás; 2014.

How to cite this article

Guimarães ACT, Cardoso CKZ, Souza LB, Guimarães MM, Peixoto MRG. Skipping breakfast among preschoolers: associated factors and its dose-response relationship with overweight/obesity. Rev Nutr. 2021;34:e200276. https://doi.org/10.1590/16789865202134200276 


\section{Methods}

This is a cross-sectional study, carried out with 463 children (24 to 59 months of age) who live in the urban location of Goiânia, Goiás, Brazil. Sociodemographic data, maternal and child nutritional status, lifestyle, and dietary practices were collected using a standardized questionnaire and Habitual Food Recall during a home-based interview. Skipping breakfast was defined as a frequency of consumption "less than seven days a week". Based on body mass index by age, children were classified as overweight/obese if Z-score $\geq 2$. Multiple logistic regression was used to assess the association between the variables surveyed and skipping breakfast. The dose-dependent relationship between breakfast frequency and overweight/obesity was determined by the trend test.

\section{Results}

The prevalence of skipping breakfast was 8.42\% (95\%IC: 6.1-11.3). There was an association between the habit of substituting dinner for a sandwich/snack (adjusted OR: 2.61, 95\%IC: 1.25-5.46; $p=0.010$ ) and the mother's overweight (adjusted OR: $2.63 ; 95 \% \mathrm{Cl}: 1.29-5.37 ; p=0.008$ ) with the habit of skipping breakfast. The trend test shows that the prevalence of overweight/obesity decreases as the frequency of breakfast consumption increases $(p=0.035)$. Additionally, when assessing the quality of breakfast, frequent consumption of foods considered unhealthy was observed.

\section{Conclusion}

There is a dose-response association between overweight/obesity and skipping breakfast. Children who substitute traditional dinner for a sandwich/snack and whose mothers are overweight are more likely to skip breakfast.

Keywords: Breakfast. Child. Feeding behavior. Overweight.

\section{R E S U M O}

\section{Objetivo}

Investigar fatores associados à omissão do café da manhã em pré-escolares e avaliar a relação dose-dependente entre frequência de consumo desta refeição e prevalência de excesso de peso.

\section{Métodos}

Estudo transversal com 463 crianças (24-59 meses de idade) da área urbana de Goiânia, Goiás, Brasil. Coletou-se dados sociodemográficos, estado nutricional materno e da criança, hábito de vida e práticas alimentares infantis usando questionário padronizado e recordatório alimentar habitual em visitas domiciliares. A omissão do café da manhã foi definida como frequência de consumo "menor que sete dias por semana". Com base no índice de massa corporal por idade, as crianças foram classificadas com excesso de peso se escore-z $\geq 2$. Utilizou-se regressão logística múltipla para avaliar associação entre as variáveis pesquisadas e a omissão do café da manhã. A relação dose-dependente entre frequência do café da manhã e excesso de peso foi determinada pelo teste de tendência.

\section{Resultados}

A prevalência de omissão do café da manhã foi 8.42\% (IC95\%: 6.1-11.3). Houve associação entre o hábito de trocar o jantar por lanche (OR ajustado: 2.61 (IC95\%:1.25-5.46); $p=0.010$ ) e o excesso de peso materno (OR ajustado: 2.63, IC95\%:1.29-5.37; $p=0.008)$ com a omissão do café da manhã. A prevalência de excesso de peso diminui quando a frequência do consumo do café da manhã aumenta $(p=0.035)$.

\section{Conclusão}

Há associação dose-resposta entre excesso de peso e omissão do café da manhã. Crianças que trocam o jantar por lanche e têm mães com excesso de peso apresentam maior chance de omitirem o café da manhã.

Palavras-chave: Desjejum. Excesso de peso. Comportamento alimentar. Criança.

\section{NTRODUCTION}

Several initiatives can promote an adequate nutritional status and the development of children, and the daily practice of having breakfast is one of them. Breakfast is associated with positive outcomes on child health; considering that it plays a critical role in energy balance, higher intake of key food groups, such as dairy, fruit and dietary fiber. Furthermore, they are also more likely to meet the recommendations 
for micronutrients [1]. In addition, breakfast consumption can improve cognitive learning and academic performance [2]. On the other hand, skipping this meal is related to a tendency to eat more energy-dense foods, leading to excess hunger and overeating [1].

Despite being considered the most important meal of the day, the incidence of skipping breakfast among children is rising $[1,2]$. Previous studies have shown that numerous factors can influence skipping breakfast, including the child's characteristics, family structure and socioeconomic status. The child's characteristics associated with skipping breakfast were being female, being older, not having a healthy BMI, having inadequate sleep and poorer diet quality [3-5]. Besides, children who were from single-parent homes, lower-income households, and with higher maternal BMI had greater odds of skipping breakfast $[6,7]$.

Skipping breakfast may have negative impacts on health, such as major risk of overweight/obesity, insulin resistance, metabolic syndrome, worse diet quality, lifestyle; when compared to those who regularly consume the meal $[8,9]$. A recent systematic review summarized the association of skipping breakfast with body weight [1]. In this study, 286.804 children and adolescents living in 33 countries were included; however, no Brazilian sample was comprised. The authors concluded that skipping breakfast was associated with overweight/obesity. However, they described that the lack of association was shown mainly in infants.

Skipping breakfast is defined as eating nothing for the first meal of the day before or at the beginning of an activity within 2 hours of waking up, usually no later than 10 am $[6,7,9]$. Furthermore, the criteria used to classify the frequency of skipping breakfast must be considered. Most of the studies use dummy (yes/no) or ordinal categories based on the number of days without having breakfast during the week. On the other hand, some others use qualitative and unspecific categories such as regularly, often and seldom. To reduce the controversial outcomes on this issue, it has been recommended that a 'dose-response' relationship between the frequency of breakfast consumption and overweight/obesity should be further investigated $[10,11]$.

International data show that overweight/obesity in children is continuing to rise [12]. Data from Brazilian children (24-59 months of age) who are attended in primary health care in the Sistema Único de Saúde (SUS, Unified Health System) showed a prevalence of $14.3 \%$ of overweight and $6.1 \%$ of obesity [13]. This situation is worrisome, considering that it can lead to an early onset of type-2 diabetes, stigmatization and depression, and also a predictor of adult coronary heart disease, diabetes and a range of cancers [12]. Overweight/obesity results from a complex network in which several factors interplay and among them, dietary habits certainly also play a role.

Considering the prevalence of overweight/obesity, the importance of breakfast consumption on child growth and development, and the controversial data between breakfast consumption and overweight/ obesity among preschoolers, the aim of the present study was to investigate the associated factors of skipping breakfast in preschoolers. The hypothesis that there is a dose-response relationship between the frequency of having breakfast and the prevalence of overweight was also tested.

\section{METHODS}

This cross-sectional, population-based and home-based study was conducted with a sample of children who live in the urban location of Goiânia, Brazil. Data of this study were derived from "Nutritional profile of children under five years old from Goiânia", which was carried out with 829 children (0 to 59 months) who were not institutionalized and did not suffer from any medical condition that was related to food disorders or anthropometric measurement. The selection of the participants was based on a complex 
process, by conglomerates of private houses, in multiple stages: drawing census tracts, homes and the child. Detailed sampling information has been published elsewhere [14].

Briefly, in this study 473 children aged 24-59 months were included. Younger children ( $<24$ months) were excluded (376 children) from the original sample and $10(2,1 \%)$ were excluded because they did not complete data, totalizing 463 children in the final sample. For this sample size, a posteriori calculation revealed a test power of 0.93 , considering the Odds Ratio (OR) of 1.50, the prevalence of the outcome in the group of non-exposed (children without overweight) of $7.68 \%$ and confidence interval of $95 \%$. $\mathrm{G}^{*}$ Power $^{\circledR} 3.1$ (Düsseldorf, Deutschland) was used to perform these analyses.

Data collection was conducted by pairs of interviews previously trained through a standardized questionnaire with questions related to identification, food consumption, and the child's and mother's anthropometry. The questions were answered by parents or the person responsible for the child. This research was approved (No. 074/11) by the Comitê de Ética da Universidade de Goiás (Ethical Committee of the University of Goiás) and was consistent with the principles expressed in the Declaration of Helsinki.

Anthropometric measures were assessed according to standardized procedures [15]. All measurements were performed with minimal clothing and without shoes. These measures were collected in duplicates. In case of a difference greater than $1 \mathrm{~kg}$ or $1 \mathrm{~cm}$, a third measurement was performed adopting the average of the two closest values in the analyses. Body Mass Index (BMI) to age was calculated and classified according to the Child Growth Standards from the World Health Organization (WHO) [16]. Nutritional status was classified into "overweight" (>Z-score+2) and "non-overweight" ( $\leq$ Z-score+2).

The frequency of breakfast consumption was assessed by the question: 'Typically, how many days a week does the child eat breakfast?'. The four response categories were: (1) every day, (2) 3-6 days a week, (3) 1-2 days a week and (4) rarely or never. Daily consumption was considered a reference category, as it represents the ideal situation. Breakfast skippers were defined as those who eat breakfast less than 7 days a week $[6,17]$. For trend analysis, the frequency of breakfast consumption was reclassified into three categories: ' $\leq 2$ days a week', '3-6 days a week' and '7 days a week'.

Additionally, the quality of the breakfast was also assessed using food consumption data from the Habitual Food Recall, which was required from the child parents/responsible adults for children [18]. Food portion sizes were quantified using household measures (e.g.: glasses, spoons), standard food portions (e.g.: apples, packages) and a picture book, including a selection of country-specific dishes in different portion sizes. The questionnaire was reviewed and agreed upon by experts in the field of nutrition. If inconsistencies were found in the Habitual Food Recall, the parents or the legal guardian were consulted for further details on the reported consumption.

Nutrition data were entered in the Avanutri® ${ }^{\circledR}$ Online software (Três Rios, Brazil). Food items that were not included in the software had their nutrition information inserted from their label. The nutrients assessed were total energy, macronutrients, dietary fiber, zinc, iron, calcium and vitamin A and C.

Breakfast energy contribution was calculated in relation to the total daily energy intake, and it was classified as insufficient ( $<16 \%)$, adequate (16 to 30\%) and excessive ( $>30 \%)$ [18]. Habitual Food Recall provides information on which food item was consumed at each time of the day, which was defined as an eating occasion. Breakfast was considered the first meal of the day, reported in the morning, before 10 o'clock $[6,7]$. Food practices (number of meals, frequency of substituting lunch or dinner for a sandwich/snack) were assessed by a standardized questionnaire.

Sociodemographic variables were obtained from a standardized questionnaire (age, gender, economic status, maternal educational level, maternal age, if the child attends daycare, maternal occupation out of home and maternal nutritional status) and lifestyle (time spent watching TV). The maternal weight and 
height (self-reported) were used to calculate the mothers' BMI and it was classified into non-overweight or overweight. Economic status is based on the Associação Brasileira de Empresas de Pesquida (ABEP, Brazilian Association of Research Companies) classification and it was classified into A/B and C/D/E classes [16,19].

Data were entered into a data file in EPI INFO ${ }^{\circledR}$ version 3.5.1 (Atlanta, USA), double-checked by Validate and analyzed using STATA ${ }^{\circledR}$, version 12 (College Station, USA). The normality of the data was checked using the Shapiro-Wilk test. Descriptive statistics were reported as means and standard deviations. Categorical data are expressed as relative frequencies. The relationship between categorical variables and breakfast consumption groups ( $<7$ days/week and 7 days/week) was examined using chi-square or Fisher's exact tests, while the relationship between continuous variables and breakfast consumption groups was examined using the Mann-Whitney test. The characteristics of children with breakfast consumption in 3-6 days/week, 1-2 days/week and rarely or never were not analyzed separately due to the small number of children in these categories.

Multivariate logistic regression modeling was performed with the variables with $p<0.2$ in bivariate analyses. Association between variables and skipping breakfast was expressed in Odds Ratio (OR) and its confidence interval $(95 \% \mathrm{Cl})$. A test for trend was performed to determine whether there is a significant dose-response relationship between the frequency of breakfast consumption and overweight/obesity as a binary response variable. For this analysis, frequency of breakfast consumption was reclassified into three categories (<2 days/week; 3-6 days/week; 7 days/week). The significance level was determined at $p<0.05$.

In addition, it was also performed a multivariate logistic regression modeling to analyze the association between skipping breakfast and overweight/obesity as an outcome variable, adjusted for child and maternal demographic variables, food intake and maternal nutritional status (data not shown).

\section{R E S U L T S}

This study was conducted with 463 preschoolers; among them, 8.42\% skipped daily breakfast. The sample showed homogeneous distribution by sex. The characteristics of preschoolers and their mothers, according to the frequency of breakfast consumption are presented in Table 1. The proportion of skipping breakfast was significantly higher among children classified as overweight/obese (16\%), who substitute lunch and dinner for a sandwich or snack (20\% and $15.91 \%$, respectively) and whose mothers were overweight $(12.50 \%)(p<0.01)$.

Table 1 - Characteristics of preschoolers and their mothers, according to the frequency of breakfast consumption, Goiânia, Goiás, Brazil. 2012 $(n=463)$.

\begin{tabular}{|c|c|c|c|c|c|c|c|}
\hline \multirow{3}{*}{ Variables } & \multirow{2}{*}{\multicolumn{2}{|c|}{ Total }} & \multicolumn{4}{|c|}{ Frequency of breakfast } & \multirow{3}{*}{$p$-value } \\
\hline & & & \multicolumn{2}{|c|}{$<7$ day/week } & \multicolumn{2}{|c|}{7 day/week } & \\
\hline & $\mathrm{n}$ & $(\%)$ & $\mathrm{n}$ & $(\%)$ & $\mathrm{n}$ & $(\%)$ & \\
\hline Total sample & & & 39 & $(8.42)$ & 424 & $(91.58)$ & 0.599 \\
\hline \multicolumn{8}{|l|}{ Age (years) } \\
\hline 2 & 166 & $(36.72)$ & 13 & $(7.83)$ & 153 & $(92.17)$ & \\
\hline 3 & 151 & (34.13) & 12 & $(7.36)$ & 151 & $(92.64)$ & \\
\hline 4 & 134 & $(29.16)$ & 14 & $(10.45)$ & 120 & $(89.55)$ & \\
\hline Sex & & & & & & & 0.364 \\
\hline Female & 234 & $(50.54)$ & 17 & $(7.26)$ & 217 & $(92.74)$ & \\
\hline Male & 229 & (49.46) & 22 & $(9.61)$ & 207 & (90.39) & \\
\hline
\end{tabular}


Table 1 - Characteristics of preschoolers and their mothers, according to the frequency of breakfast consumption, Goiânia, Goiás, Brazil. 2012 $(n=463)$.

\begin{tabular}{|c|c|c|c|c|c|c|c|}
\hline \multirow{3}{*}{ Variables } & \multirow{2}{*}{\multicolumn{2}{|c|}{ Total }} & \multicolumn{4}{|c|}{ Frequency of breakfast } & \multirow{3}{*}{$p$-value } \\
\hline & & & \multicolumn{2}{|c|}{$<7$ day/week } & \multicolumn{2}{|c|}{7 day/week } & \\
\hline & $\mathrm{n}$ & $(\%)$ & $n$ & $(\%)$ & $n$ & $(\%)$ & \\
\hline Economic status & & & & & & & 0.337 \\
\hline$A / B$ & 169 & $(36.50)$ & 17 & $(10.06)$ & 152 & $(89.94)$ & \\
\hline$C / D / E$ & 294 & $(63.50)$ & 22 & $(7.48)$ & 272 & $(95.52)$ & \\
\hline Attending daycare & & & & & & & 0.925 \\
\hline No & 300 & $(64.79)$ & 25 & (8.33) & 275 & $(91.67)$ & \\
\hline Yes & 163 & $(35.21)$ & 14 & $(8.59)$ & 149 & $(91.41)$ & \\
\hline Time watching TV & & & & & & & 0.863 \\
\hline$<3$ hours & 240 & (53.93) & 21 & $(8.75)$ & 219 & $(91.25)$ & \\
\hline$\geq 3$ hours & 205 & $(46.07)$ & 17 & $(8.29)$ & 188 & $(91.71)$ & \\
\hline Overweight & & & & & & & 0.048 \\
\hline No & 403 & $(89.01)$ & 31 & (7.69) & 372 & $(92.31)$ & \\
\hline Yes & 50 & $(11.04)$ & 8 & $(16.00)$ & 42 & $(84.00)$ & \\
\hline Substituting lunch for sandwich/snack & & & & & & & 0.004 \\
\hline$<3$ times/week & 414 & $(90.20)$ & 30 & $(7.25)$ & 384 & $(92.75)$ & \\
\hline$\geq 3$ times/week & 45 & $(9.80)$ & 9 & $(20.00)$ & 36 & $(80.00)$ & \\
\hline Substituting dinner for sandwich/snack & & & & & & & 0.006 \\
\hline$<3$ times/week & 371 & $(80.83)$ & 25 & $(6.74)$ & 346 & $(93.26)$ & \\
\hline$\geq 3$ times/week & 88 & $(19.17)$ & 14 & $(15.91)$ & 74 & $(84.09)$ & \\
\hline Number of meals/day & & & & & & & 0.362 \\
\hline$<5$ & 41 & $(9.11)$ & 5 & $(12.20)$ & 36 & $(87.80)$ & \\
\hline$\geq 5$ & 422 & (91.14) & 34 & $(8.06)$ & 388 & $(91.94)$ & \\
\hline Maternal age (years) & & & & & & & 0.525 \\
\hline$<30$ & 257 & $(56.11)$ & 20 & $(7.78)$ & 237 & $(92.22)$ & \\
\hline$\geq 30$ & 201 & $(43.89)$ & 19 & $(9.45)$ & 187 & $(90.55)$ & \\
\hline Maternal educational level & & & & & & & 0.254 \\
\hline$<9$ (years) & 119 & $(26.21)$ & 7 & $(5.88)$ & 112 & $(94.12)$ & \\
\hline$\geq 9$ (years) & 335 & $(73.79)$ & 31 & $(9.25)$ & 304 & $(90.75)$ & \\
\hline Maternal occupation out of home & & & & & & & 0.788 \\
\hline No & 185 & $(40.48)$ & 15 & $(8.11)$ & 170 & $(91.89)$ & \\
\hline Yes & 272 & $(59.52)$ & 24 & $(8.82)$ & 248 & $(91.18)$ & \\
\hline Maternal overweight & & & & & & & 0.010 \\
\hline No & 237 & $(55.24)$ & 13 & $(5.49)$ & 224 & $(94.51)$ & \\
\hline Yes & 192 & $(44.76)$ & 24 & $(12.50)$ & 168 & $(87.50)$ & \\
\hline
\end{tabular}

Note: ${ }^{* *}$ Pearson Chi Square test or Fisher's Exact test. The differences in absolute frequencies correspond to the missing values..

The risk of skipping breakfast was higher among children who substitute lunch $(p=0.005)$ and dinner $(p=0.007)$ for sandwiches/snacks more than 3 times a week and whose mothers are classified as overweight $(p=0.012)$. These variables, as well as gender, overweight/obesity, number of daily meals and maternal educational level were tested in adjusted models. The analysis of bivariate logistic regression and the multiple logistic regression results are shown in Table 2.

Preschoolers prevalence of overweight/obesity, according to the consumption of breakfast up to $\leq 2$ times/week was 25\% (95\% Cl: 7.26-52.38), 3-6 times/week was $17.39 \%(95 \% \mathrm{Cl}: 4.95-38.78)$ and 7 times/week was $10.14 \%(95 \% \mathrm{Cl}: 7.41-13.46)$. The prevalence of overweight/obesity among preschoolers decreased as the frequency of breakfast consumption increased ( $p$ trend=0.035; Figure 1). 
Table 2 - Associated factors with skipping breakfast among preschoolers from Goiânia, Goiás, Brazil ( $\mathrm{n}=463)$.

\begin{tabular}{|c|c|c|c|c|c|c|}
\hline \multirow{2}{*}{ Variable } & \multicolumn{3}{|c|}{ Bivariate } & \multicolumn{3}{|c|}{ Adjusted analyses } \\
\hline & OR & $\mathrm{Cl}(95 \%)$ & $p$-value & $\mathrm{OR}$ & $\mathrm{Cl}(95 \%)$ & $p$-value \\
\hline \multicolumn{7}{|l|}{ Age (years) } \\
\hline 2 & 1.00 & - & & & & \\
\hline 3 & 0.83 & $(0.37 ; 1.89)$ & 0.664 & & & \\
\hline 4 & 1.29 & $(0.59 ; 2.81)$ & 0.522 & & & \\
\hline \multicolumn{7}{|l|}{ Sex } \\
\hline Female & 1.00 & - & & & & \\
\hline Male & 1.36 & $(0.70 ; 2.63)$ & 0.366 & & & \\
\hline \multicolumn{7}{|l|}{ Attending daycare } \\
\hline Yes & 1.00 & - & & & & \\
\hline No & 0.98 & $(0.69 ; 1.38)$ & 0.925 & & & \\
\hline \multicolumn{7}{|l|}{ Time watching TV } \\
\hline$<3$ hours & 1.00 & - & & & & \\
\hline$\geq 3$ hours & 0.91 & $(0.47 ; 1.77)$ & 0.793 & & & \\
\hline \multicolumn{7}{|l|}{ Overweight/obesity } \\
\hline No & 1.00 & - & & 1.00 & - & \\
\hline Yes & 2.24 & $(0.99 ; 5.29)$ & 0.054 & 1.82 & $(0.76 ; 4.35)$ & 0.180 \\
\hline \multicolumn{7}{|c|}{ Substituting lunch for sandwich/snack } \\
\hline$<3$ times/week & 1.00 & - & & 1.00 & - & \\
\hline$\geq 3$ times/week & 3.2 & $(1.41 ; 7.26)$ & 0.005 & 1.81 & $(0.67 ; 4.89)$ & 0.241 \\
\hline \multicolumn{7}{|c|}{ Substituting dinner for sandwich/snack } \\
\hline$<3$ times/week & 1.00 & - & & 1.00 & & \\
\hline$\geq 3$ times/week & 2.62 & $(1.30 ; 5.28)$ & 0.007 & 2.61 & $(1.25 ; 5.46)$ & 0.010 \\
\hline \multicolumn{7}{|l|}{ Number of meals/day } \\
\hline$<5$ & 1.58 & $(0.78 ; 4.30)$ & 0.366 & & & \\
\hline$\geq 5$ & 1.00 & - & & & & \\
\hline \multicolumn{7}{|l|}{ Maternal age } \\
\hline$<30$ years & 1.00 & - & & & & \\
\hline$\geq 30$ years & 1.24 & $(0.64 ; 2.39)$ & 0.526 & & & \\
\hline \multicolumn{7}{|c|}{ Maternal educational level } \\
\hline$<9$ (years) & 1.00 & - & & & & \\
\hline$\geq 9$ (years) & 1.63 & $(0.70 ; 3.81)$ & 0.258 & & & \\
\hline \multicolumn{7}{|c|}{ Maternal occupation out of home } \\
\hline No & 1.00 & - & & & & \\
\hline Yes & 1.13 & $(0.58 ; 2.22)$ & 0.712 & & & \\
\hline \multicolumn{7}{|l|}{ Maternal overweight } \\
\hline No & 1.00 & - & & 1.00 & - & \\
\hline Yes & 2.46 & $(1.22 ; 4.98)$ & 0.012 & 2.63 & $(1.29 ; 5.37)$ & 0.008 \\
\hline
\end{tabular}

Note: OR: Odds Ratio; C195\%: Confidence Interval of $95 \%$ for OR.

Data on food intake are shown in Table 3. Energy intake during breakfast was adequate for $51.7 \%$ of children, insufficient for $41.8 \%$ and excessive for $6.5 \%$. As $60.6 \%$ of children reported using baby bottles, it explains the high frequency of thickener during breakfast. There was no significant difference in nutrient intake by frequency of breakfast consumption (Table 4).

\section{DISCUSSION}

The findings from this study showed that substituting dinner for a sandwich/snack three or more times/week and maternal overweight increased the likelihood of skipping breakfast in preschoolers. A 


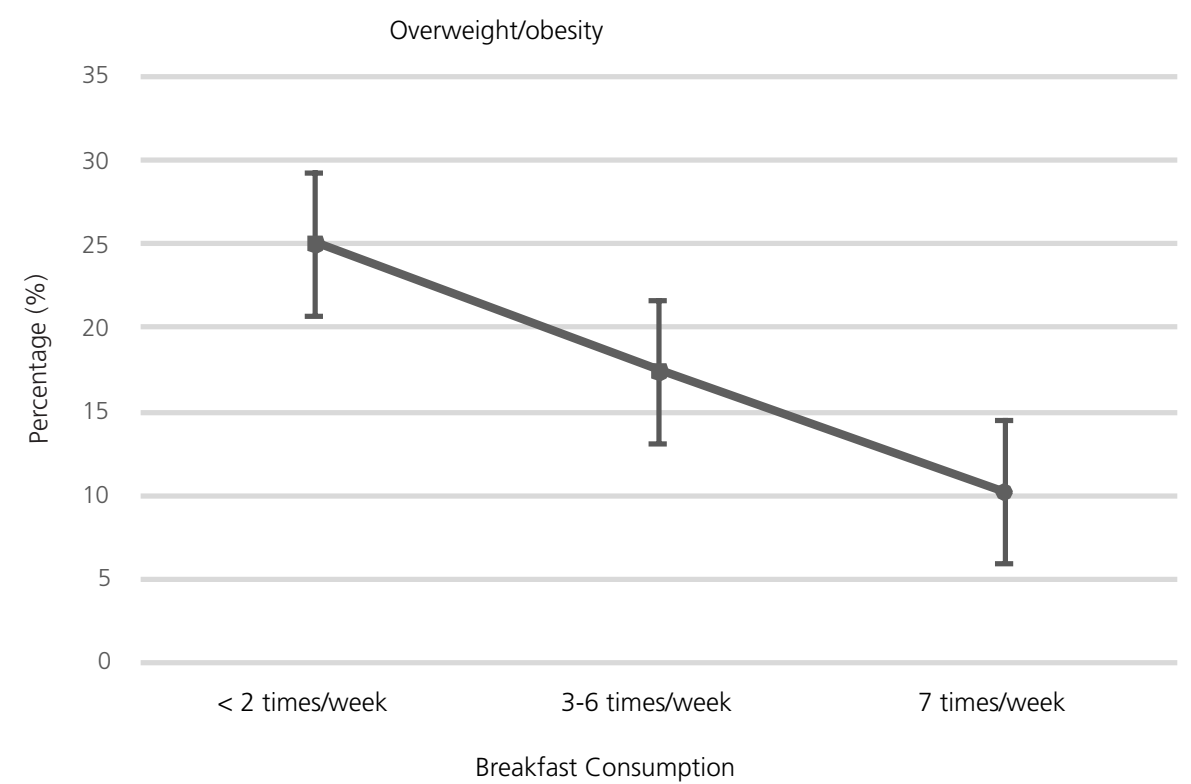

Figure 1 - Prevalence of overweight by breakfast consumption among preschoolers from Goiânia, Goiás, Brazil $(n=453)$. Note: Test for trend: $p=0.035$.

Table 3 - Types of food (\%) usually consumed during breakfast by preschoolers from Goiânia, Goiás, Brazil. 2012 ( $n=463)$.

\begin{tabular}{|c|c|}
\hline Types of food & $\%$ \\
\hline Dairy & 89.7 \\
\hline Sugar-rich foods ${ }^{1}$ & 61.1 \\
\hline Bread $^{2}$ & 42.1 \\
\hline Tickener $^{3}$ & 27.1 \\
\hline $\mathrm{Fat}^{4}$ & 18.5 \\
\hline Bakery products 5 & 13.5 \\
\hline Fruit/ Natural Fruit Juice & 8.2 \\
\hline Ham/Mortadella/Sausage & 2.64 \\
\hline Sandwich cookies & 1.2 \\
\hline Coffee,tea & 14.0 \\
\hline
\end{tabular}

Note: ${ }^{1}$ Added sugar, chocolate milk, jam, industrialized juices. ${ }^{2}$ Bread, toast, starch biscuit. 4Maize starch, Farinha Láctea ${ }^{\circledR}$, Mucilon ${ }^{\circledast}$ or $\mathrm{Cremogema}^{\circledR}$ ${ }^{4}$ Butter, margarine. ${ }^{5}$ Cheese bread, cheese biscuit, cake.

Table 4 - Total nutrient intake median $(95 \%$ Cl) for breakfast frequency in preschoolers from Goiânia, Goiás, Brazil. 2012 ( $n=463)$.

\begin{tabular}{|c|c|c|c|}
\hline \multirow{2}{*}{ Nutrients } & \multicolumn{2}{|c|}{ Breakfast frequency } & \multirow{2}{*}{$p$-value } \\
\hline & $<7$ days/week & 7 days/week & \\
\hline Energy (kcal) & $1560.9(1414.7 ; 1707.1)$ & $1582.1(1537.7 ; 1626.4)$ & 0.787 \\
\hline Total fat (g) & $29.3(27.3 ; 31.2)$ & $27.7(27.1 ; 28.2)$ & 0.096 \\
\hline Protein (g) & $16.1(14.6 ; 17.4)$ & $16.9(16.6 ; 17.4)$ & 0.169 \\
\hline Carbohydrate (\%) & $54.2(51.6 ; 56.7)$ & $54.9(54.1 ; 55.6)$ & 0.065 \\
\hline Dietary fiber (g) & $9.7(8.2 ; 11.3)$ & $10.8(10.2 ; 11.3)$ & 0.249 \\
\hline Vitamin A $(\mu \mathrm{g})$ & $509.1(377.3 ; 640.9)$ & $559.2(512.7 ; 605.6)$ & 0.531 \\
\hline Vitamin C (mg) & $64.9(45.6 ; 84.3)$ & $59.5(53.5 ; 65.5)$ & 0.604 \\
\hline Calcium (mg) & $724.9(569.3 ; 880.5)$ & $757.5(717.5 ; 797.4)$ & 0.644 \\
\hline Iron (mg) & $9.4(7.9 ; 10.9)$ & $9.5(9.1 ; 9.9)$ & 0.919 \\
\hline Zinc (mg) & $7.9(5.7 ; 9.0)$ & $8.1(7.6 ; 8.5)$ & 0.379 \\
\hline
\end{tabular}

Note: *Mann-Whitney Test. g: Gram; mg: Miligram; $\mu$ g: Microgram. 
relationship between skipping breakfast and children overweight/obesity was not observed when performing the multivariate regression. However, the prevalence of overweight/obesity decreased as the frequency of breakfast consumption increased. This result supports the hypothesis that there is a dose-response relationship between the frequency of breakfast consumption and overweight/obesity in preschoolers, as it was described for Asian adults $[10,11]$.

The prevalence of skipping breakfast we described is in accordance with (8.4\%) Monzani et al. [1] who described, in a systematic review, the prevalence of breakfast skippers ranging from 1.3 to $74.7 \%$, according to different definitions used for skipping breakfast, as they vary across studies. Dubois et al. [17] reported a prevalence of breakfast skippers similar $(9,8 \%)$ to ours when assessing Canadian preschoolers (2-5 years), using the same definition of skipping breakfast. Al-Hazzaa et al. [6], when assessing Saudi children (5.9 to 13.4 years), found a higher prevalence (79\%) of skipping daily breakfast. Studies from other countries, using different definition for skipping breakfast and age groups (children and adolescents) described different prevalence of skipping breakfast: Australia [7] (4\%), USA [20] (4\%), France [21] (9.8\%), Malaysia [22] (11.7\%), Italy [23] (14.8\%), Iran [24] (18.9\%), Greece [25] (22.4-23.1\%). Information about breakfast among preschoolers in Brazil is limited; however, it was described in literature and studies with Brazilian adolescents [26,27] (7.0-9.6\%) and adults [28] (29.4-36.3\%).

Such findings revealed that skipping breakfast is a common habit that permeates different strata of age and socioeconomic development, as described in literature and observed in our study $[1,3,29]$. Children skipping breakfast is a potential problem as it is associated with negative outcomes on their health and cognitive learning $[2,8,30]$. Besides, an increasing trend in skipping breakfast from childhood to adolescence has been observed [1]; hence, this period of life became a crucial opportunity for interventions and reinforcing the importance of breakfast consumption.

We observed a significant association between substituting dinner for a sandwich/snack and skipping breakfast after adjustment for other risk factors. Ramsay et al. [20] explain that children who skip breakfast tend to skip other meals during the day. A longitudinal study in Canada [17] found that children aged 44-56 months, who skipped breakfast, consumed more energy and macronutrients from snacks than from meals; therefore, skipping breakfast may contribute to an unhealthy daily dietary pattern. Although breakfast skippers were described to have lower diet quality, as described previously in literature, daily energy intake was comparable to those who had breakfast every day, revealing that energy intake missed from skipping breakfast was compensated through foods consumed later in the day, specifically at evening snacks $[17,24,31]$. On the other hand, consuming excessive energy at dinner may reduce appetite in the morning [3].

Contradictory to expected [10,24,32-36], skipping breakfast was not associated with overweight/ obesity, after adjustment for risk factors such as socioeconomic status, sex, age, the child's eating habits, the child and maternal nutritional status, and maternal occupation. Jeans et al. [37] did not find a significant relationship between breakfast consumption and anthropometric measurements, as well as a recent prospective study [38] with 2.5-4.5-year-old children. However, studies conducted with children and adolescents showed an association between overweight/obesity and the frequency of breakfast consumption $[10,11]$. Despite specific physiological characteristics of each age group, such as irregular appetite and slow and steady linear growth in preschool-aged, cross-sectional studies support that skipping breakfast is associated with overweight/obesity, independently of the age $[9,10]$. The difference between our findings and those from other studies may be because most of them included children older than the ones included in our study (24-59 months). Besides that, the variety of definitions used for skipping breakfast across studies and the adjusted variables used in the regression model may also have contributed to the difference in results. 
However, we observed a dose-response relationship between overweight/obesity and skipping breakfast when three categories of breakfast consumption were considered. The prevalence of overweight/ obesity increased as the frequency of breakfast consumption decreased. According to Huang et al. [11] a dose-response relationship between the frequency of breakfast consumption and the risk of obesity not only is the protective role of eating breakfast in preventing obesity underscored, but also highlights breakfast skipping as a potential target for intervention in combating the obesity pandemic.

Maternal overweight was found to be positively associated with skipping breakfast among preschoolers. This finding is consistent with a previous study, which indicated that skipping breakfast was more common among children of overweight/obese mothers [4]. Possible explanations for this fact are that overweight/obese adults were more likely to skip breakfast and that parents who skipped breakfast were likely to have children who did the same $[8,10,39]$.

In our study, age, maternal educational level and the fact of working out of home were not related to the habit of skipping breakfast. These findings contrast with the fact that maternal age over 40 years, low education level, working hours and child routines can interfere with the omission of meals and family meals $[9,40,41]$. Possibly this contrast is due to different sociodemographic characteristics between the sample of the studies. Family meals have a beneficial effect on the nutritional status and eating behavior of children [41]. They are also an opportunity to value mealtime and to adopt healthy eating habits [42]. The influence of parents on the formation of a child's eating habits is well-recognized $[8,43]$ and indicates the importance of responsive eating practices in preventing skipping breakfast, overweight/obesity and eating difficulties $[44,45]$. This reinforces the need to encourage positive parental care in infant feeding and to promote food education for the structuring of healthy eating habits in the family. Thus, the food guide for the Brazilian population emphasizes that shared meals at home are excellent opportunities for children to acquire good habits and recognize the importance of regular meals and make it in an appropriate ambience [46].

When analyzing food intake during breakfast, it was possible to infer that the meal was monotonous, mainly composed of dairy products, sugar-rich foods, low intake of fruits, cereals, and whole grains. Although breakfast composition varies across the world, it is noteworthy that children, according to recommendations, should be encouraged to eat dairy products, fruits, whole grain bread/cereals instead of refined products and sugary drinks to improve the quality of the meal $[8,21,35,46,47]$. As the consumption of dairy products was highly prevalent, thickener was widely used in this sample because of baby bottles. Thickener, normally made from rice or maize, gum-based thickeners from guar or locust bean, and carboxymethyl cellulose should be replaced by other food with a lower concentration of sugar and higher dietary fiber to improve its intake [48].

Breakfast skippers showed the mean intake of dietary fiber similar to those who ate breakfast in this study, as it is described for Brazilian adolescents (consumers vs. occasional consumers vs skippers. $p=0.114$ ) [27]. Possibly this is due to the content of traditional Brazilian patterns of breakfast and the lack of fiber-rich foods in this meal. According to Pereira et al. [27], when analyzing the breakfast of Brazilian adolescents, the most frequently consumed food groups at this meal are white bread, coffee, milk, butter/margarine, refined grain cookies, cakes and sweet pies, typical Brazilian dishes (pamonha, couscous), juices, processed meats, eggs, chocolate powder, pizza and salty goods (esfiha, Brazilian cheese puffs) and fruits. Differently from our results, it is described in literature that children who consume breakfast have higher nutrient intake and are more likely to consume healthier diets [7,24]. Ramsay et al. [20] described a significantly higher intake of dietary fiber (11.4×9.6 grams) among children who eat breakfast when compared to those who skipped it. The same was described for the Health Eating Index score of fruits (3.6x2.5) and whole grains (2.5x1.2). Considering that Adequate Intake for children under 3 years is 19 grams, and 25 grams for children aged 4-8 years, in both studies, dietary fiber intake was below recommendation [49]. 
Not only is food diversity important to meeting nutritional requirements, but also the distribution of Total Energy Intake (TEI) per meal. Average energy intake during breakfast was $18 \%$ of TEl, which is below the recommendation for an adequate breakfast (20 a $25 \%$ of TEI) [50]. Smith et al. [8] described similar breakfast energy intake (18\%) among Australian children, while Lepicard et al. [21] described a higher contribution $(22,9 \%)$ among French children. Most of the preschoolers $(51.7 \%)$ consumed an adequate amount of energy, although a considerable percentage (41.8\%) of participants consumed less energy than the recommended for breakfast.

The results of the present study must be considered in the light of certain limitations. First, this study was conducted with children aged 24-59 months and it does not cover the entire age group of the pre-school phase, which extends up to the age of 69 months. Secondly, the reason why breakfast was skipped was not investigated. Finally, we can mention the limitation of the responses and memory biases in the application of the food record. However, it is a population-based study in an age group that needs more studies to better understand the practice of having breakfast and its associated factors. Then, the present study makes important contributions to literature and further understanding of the association between breakfast skipping and overweight/obesity in preschoolers.

\section{CONCLUSION}

We conclude that there is a dose-response between overweight/obesity and skipping breakfast, whereas the prevalence of overweight/obesity among preschoolers increased as the frequency of breakfast consumption decreased. Moreover, children whose mothers are overweight are more likely to skip breakfast and skipping breakfast is associated with inadequate food habits, like substituting dinner for a sandwich/ snack. Among breakfast eaters, the meal was, in general, monotonous, with a low intake of fruits and whole grains and a high intake of dairy products and sugar-rich foods. Thus, we emphasize the importance of developing strategies to encourage regular breakfast consumption in preschoolers and the inclusion of healthy foods not only in breakfast but in all meals, as well as encouraging responsive eating practices.

\section{CONTRIBUTORS}

ACVT Guimarães and CKS Cardoso were responsible for data collection, analysis and interpretation, writing and final approval. LB Souza and MM Guimarães contributed to the interpretation of data, writing and final approval. MRG Peixoto was responsible for the conception, design, analysis and interpretation of data, review and final approval.

\section{REFERENCES}

1. Monzani A, Ricotti R, Caputo M, Solito A, Archero F, Bellone S, et al. A systematic review of the association of skipping breakfast with weight and cardiometabolic risk factors in children and adolescents. What Should We Better Investigate in the Future? Nutrients. 2019;11(2):387. https://doi.org/10.3390/nu11020387

2. Adolphus $\mathrm{K}$, Lawton $\mathrm{CL}$, Champ CL, Dye L. The effects of breakfast and breakfast composition on cognition in children and adolescents: a systematic review. Adv Nutr. 2016;7(3):590S-612S. https://doi.org/10.3945/an.115.010256

3. Ardeshirlarijani E, Namazi N, Jabbari M, Zeinali M, Gerami H, Jalili R, et al. The link between breakfast skipping and overweigh/obesity in children and adolescents: a meta-analysis of observational studies. J Diabetes Metab Disord. 2019;18:657-64. https://doi.org/10.1007/s40200-019-00446-7

4. Alsharairi NA, Somerset SM. Skipping breakfast in early childhood and its associations with maternal and child BMI: a study of 2-5-year-old Australian children. Eur J Clin Nutr. 2016;70(4):450-5. https://doi.org/10.1038/ejcn.2015.184 
5. Okada C, Tabuchi T, Iso H. Association between skipping breakfast in parents and children and childhood overweight/ obesity among children: a nationwide 10.5-year prospective study in Japan. Int J Obes. 2018;42(10):1724-32. https://doi.org/10.1038/s41366-018-0066-5

6. Al-Hazzaa HM, Alhowikan AM, Alhussain MH, Obeid OA. Breakfast consumption among Saudi primary-school children relative to sex and socio-demographic factors. BMC Public Health. 2020;20:448. .https://doi.org/10.1186/ s12889-020-8418-1

7. Fayet-Moore F, Kim J, Sritharan N, Petocz P. Impact of breakfast skipping and breakfast choice on the nutrient intake and body mass index of australian children. Nutrients. 2016;8(8):487. https://doi.org/10.3390/nu8080487

8. Smith KJ, Breslin MC, McNaughton SA, Gall SL, Blizzard L, Venn AJ. Skipping breakfast among Australian children and adolescents; findings from the 2011-12 National Nutrition and Physical Activity Survey. Aust N Z J Public Health. 2017;41(6):572-8. http://doi.org/10.1111/1753-6405.12715

9. Kesztyüs D, Traub M, Lauer R, Kesztyüs T, Michael Steinacker J. Skipping breakfast is detrimental for primary school children: cross-sectional analysis of determinants for targeted prevention. BMC Public Health. 2017;17:258. https:// doi.org/10.1186/s12889-017-4169-z

10. Ma X, Chen Q, Pu Y, Guo M, Jiang Z, Long YW, et al. Skipping breakfast is associated with overweight and obesity: A systematic review and meta-analysis. Obes Res Clin Prac. 2020;14:1-8. https://doi.org/10.1016/j.orcp.2019.12.002

11. Huang CJ, Hu HT, Fan YC, Liao YM, Tsai PS. Associations of breakfast skipping with obesity and health-related quality of life: evidence from a national survey in Taiwan. Int J Obes (Lond). 2010;34(4):720-5. https://doi.org/10.1038/ ijo.2009.285

12. United Nations Children's Fund. The State of the World's Children 2019. Children, Food and Nutrition: Growing well in a changing world [cited 2021 Jun 3]. New York: UNICEF; 2019. Available from: https://www.unicef.org/reports/ state-of-worlds-children-2019

13. Ministério da Saúde (Brasil). Atlas da Obesidade Infantil no Brasil. Brasília: Ministério; 2019 [cited 2021 Jun 3]. Available from: https://189.28.128.100/dab/docs/portaldab/publicacoes/dados_atlas_obesidade.pdf

14. Lemes MGC, Peixoto MRG, Meneses IHF, Freire MCM. Dor dentária e fatores associados em crianças de 2 a 4 anos de idade de Goiânia. Rev Bras Epidemiol. 2015;18:630-41.

15. Lohman TG, Roche AF, Martorell R. Anthropometric standardization reference manual. Champaign: Human Kinetics Books; 1988.

16. World Health Organization. Physical status: the use and interpretation of anthropometry. Geneva: Organization; 2013 [cited 2020 Mar 6] Available from: https://www.who.int/childgrowth/publications/physical_status/en/

17. Dubois L, Girard M, Potvin Kent M, Farmer A, Tatone-Tokuda F. Breakfast skipping is associated with differences in meal patterns, macronutrient intakes and overweight among pre-school children. Public Health Nutr. 2009;12(1):19-28. https://doi.org/10.1017/S1368980008001894

18. Garcia MT, Granado FS, Cardoso MA. Alimentação complementar e estado nutricional de crianças menores de dois anos atendidas no Programa Saúde da Família em Acrelândia, Acre, Amazônia Ocidental Brasileira. Cad Saúde Pública. 2011;27(2):305-16. https://doi.org/10.1590/S0102-311X2011000200012

19. Associação Brasileira de Empresas de Pesquisa. Critério Padrão de Classificação Econômica Brasil. 2008 [cited 2020 Mar 5]. Available from: http://www.abep.org/codigosguias/Criterio_Brasil_2008.pdf

20. Ramsay SA, Bloch TD, Marriage B, Shriver LH, Spees CK, Taylor CA. Skipping breakfast is associated with lower diet quality in young US children. Eur J Clin Nutr. 2018;72:548-56. https://doi.org/10.1038/s41430-018-0084-3

21. Lepicard E, Maillot M, Vieux F, Viltard M, Bonnet F. Quantitative and qualitative analysis of breakfast nutritional composition in French schoolchildren 9 to 11 years of age. J Hum Nutr Diet. 2017;30(2):151-8. https://doi. org/10.1111/jhn. 12412

22. Tee ES, Nurliyana AR, Karim Norimah A, Jan Mohamed HJB, Tan SY, Appukutty M, et al. Breakfast consumption among Malaysian primary and secondary school children and relationship with body weight status : findings from the MyBreakfast Study. Asia Pac J Clin Nutr. 2018;27(2):421-32. https://doi.org/10.6133/apjcn.062017.12

23. Archero F, Ricotti R, Solito A, Carrera D, Civello F, Di Bella R, et al. Adherence to the mediterranean diet among school children and adolescents living in Northern Italy and unhealthy food behaviors associated to overweight. Nutrients. 2018;10(9):1322. https://doi.org/10.3390/nu10091322

24. Ahadi Z, Qorbani M, Kelishadi R, Ardalan G, Motlagh ME, Asayesh H, et al. Association between breakfast intake with anthropometric measurements, blood pressure and food consumption behaviors among Iranian children and adolescents: The CASPIAN-IV study. Public Health. 2015;129(6):740-7. https://doi.org/10.1016/j.puhe.2015.03.019 
25. Tambalis KD, Panagiotakos DB, Psarra G, Sidossis LS. Breakfast skipping in Greek schoolchildren connected to an unhealthy lifestyle profile. Results from the National Action for Children's Health program. Nutr Diet. 2019;76(3):328-35. http://doi.org/10.1111/1747-0080.12522

26. Hassan BK, Cunha DB, Valeria Da Veiga G, Alves Pereira R, Sichieri R. Changes in breakfast frequency and composition during adolescence: The Adolescent Nutritional Assessment Longitudinal Study, a cohort from Brazil. Plos One. 2018;19;13(7):e0200587. http://doi.org/10.1371/journal.pone.0200587

27. Pereira JL, Castro MA, Hopkins S, Gugger C, Fisberg RM, Fisberg M. Prevalence of consumption and nutritional content of breakfast meal among adolescents from the Brazilian National Dietary Survey. J Pediatr. 2018;94:630-41.

28. Baltar VT, Cunha DB, Santos RO, Marchioni DM, Sichieri R. Breakfast patterns and their association with body mass index in Brazilian adults. Cad. Saúde Pública. 2018;34(6):e00111917. https://doi.org/10.1590/0102-311x00111917

29. Otaki N, Obayashi K, Saeki K, Kitagawa M, Tone N, Kurumatani N. Relationship between breakfast skipping and obesity among elderly: cross-sectional analysis of the HEIJO-KYO study. J Nutr Health Aging. 2017; 21(5):501-4. https://doi.org/10.1007/s12603-016-0792-0

30. Liu J, Gibson D, Stearne K, Dobbin SW. Skipping breakfast and non-high-density lipoprotein cholesterol in school children : preliminary analysis. Public Health. 2019;168:46. https://doi.org/10.1016/j.puhe.2018.12.006

31. Betts JA, Chowdhury EA, Gonzalez JT, Richardson JD, Tsintzas K, Thompson D. Is breakfast the most important meal of the day? Proc Nutr Soc. 2016;74(4):464-74. http://doi.org/10.1017/S0029665116000318

32. Paduano S, Borsari L, Salvia C, Arletti S, Tripodi A, Pinca J, et al. Risk factors for overweight and obesity in children attending the first year of primary schools in Modena, Italy. J Community Health. 2019;45(2):301-9. https://doi. org/10.1007/s10900-019-00741-7

33. Ikeda N, Nishi N. First incidence and associated factors of overweight and obesity from preschool to primary school: longitudinal analysis of a national cohort in Japan. Int J Obes. 2019;43(4):751-60. https://doi.org/10.1038/s41366018-0307-7

34. Wu CH, Lin CY, Hsieh YP, Strong C, Meshki C, Lin YC, et al. Dietary behaviors mediate the association between food insecurity and obesity among socioeconomically disadvantaged youth. Appetite. 2019;132:275-81. https://doi. org/10.1016/j.appet.2018.10.013

35. Nielsen B, Yngve A, Monteagudo C, Tellstrom R, Scander H, Werner B. Reported habitual intake of breakfast and selected foods in relation to overweight status among seven- to nine-year-old Swedish children. Scand J Public Health. 2017;45:886-94. https://doi.org/10.1177\%2F1403494817724951

36. Ofori-Asenso R, Owen AJ, Liew D. Skipping breakfast and the risk of cardiovascular disease and death: a systematic review of prospective cohort studies in primary prevention settings. J Cardiovasc Dev Dis. 2019;6(3):30. https://doi. org/10.3390/jcdd6030030

37. Jeans M, Asigbee F, Landry M, Vandyousefi S, Ghaddar R, Leidy H, et al. Breakfast consumption in low-income hispanic elementary school-aged children: associations with anthropometric, metabolic, and dietary parameters. Nutrients. 2020;12(7):2038-55. https://doi.org/10.3390/nu12072038

38. Yaguchi-Tanaka Y, Tabuchi T. Skipping breakfast and subsequent overweight/obesity in children: A nationwide prospective study of 2.5 to 13-year olds in Japan. J Epidemiol. 2020. Online ahead of print. https://doi.org/10.2188/ jea.JE20200266

39. Okada C, Tabuchi T, Iso H. Association between skipping breakfast in parents and children and childhood overweight/ obesity among children: a nationwide 10.5-year prospective study in Japan. Int J Obes. 2018;42(10):1724-32. https://doi.org/10.1038/s41366-018-0066-5

40. Sato PM, Lourenço BH, Trude ACB, Unsain RF, Pereira PR, Martins PA, Scagliusi FB. Family meals and eating practices among mothers in Santos, Brazil: a population-based study. Appetite. 2016;103:38-44. https://doi.org/10.1016/j. appet.2016.03.018

41. Tosatti, AM, Ribeiro LW, Machado RHV, Maximino P, Bozzini AP, Ramos CC, et al. Does family mealtime have a protective effect on obesity and good eating habits in young people? A 2000-2016 review. Rev Bras Matern Infant. 2017;17(3). https://doi.org/10.1590/1806-93042017000300002

42. Litterbach EKV, Campbell KJ, Spence AC. Family meals with young children: an online study of family mealtime characteristics, among Australian families with children aged six months to six years. BMC Public Health. 2017;17. https://doi.org/10.1186/s12889-016-3960-6

43. Silva GAP, Costa KAO, Giugliani ERJ. Infant feeding: beyond the nutritional aspects. J Pediatr. 2016;92:S2-S7. https:// doi.org/10.1016/j.jped.2016.02.006 
44. Lindsay AC, Sitthisongkram S, Greaney ML, Wallington SF, Ruengdej P. Non-responsive feeding practices, unhealthy eating behaviors, and risk of child overweight and obesity in Southeast Asia: a systematic review. Int J Environ Res Public Health. 2017;14(4):436. https://doi.org/10.3390/ijerph14040436

45. Maranhão HS, Aguiar RC, Lira DTJ, Sales, MUF, Nóbrega NAN. Dificuldades alimentares em pré-escolares, práticas alimentares pregressas e estado nutricional. Rev Paul Pedriatr. 2018;36(1):45-51. https://doi.org/10.1590/19840462/;2018;36;1;00004

46. Ministério da Saúde (Brasil). Guia Alimentar para a População Brasileira. Brasília: Ministério da Saúde, 2014 [cited 2020 Mar 18]. Available from: https://www.saude.gov.br/bvs

47. Fayet-Moore F, Mcconnell A, Tuck K, Petocz P. Breakfast and breakfast cereal choice and its impact on nutrient and sugar intakes and anthropometric measures among a nationally representative sample of Australian children and adolescents. Nutrients. 2017;9(10):1045. https://doi.org/10.3390/nu9101045

48. Kwok T, Ojha S, Dorling J. Feed thickener for infants up to six months of age with gastro-oesophageal reflux. Cochrane Database Syst Rev. 2017;(12):1-256. https://doi.org/10.1002/14651858.cd003211.pub2

49. Dietary Reference Intakes. Dietary Reference Intakes (DRI) for energy, carbohydrate, fiber, fat, fatty acids, cholesterol, protein, and amino acids. 2002 [cited 2020 Mar 18]. Available from: http://www.nap.edu

50. Phillipi ST. Pirâmide Dos Alimentos: Fundamentos Básicos da Nutrição. 3a . ed. São Paulo: Saraiva; 2018. 